\title{
Effect of Different Cell Suspension Culture Densities of Physalis angulata L. by Using Plating or Embedding Methods on the Callus Formation تاثير كثافات زراعة المعلقات الخلوية لنبات .Physalis angulata L بطريقة النشر أوالطمر على تكوين بائيات الكالس
}

\author{
Muthana Muhamad Al-Mahdawe Talfan Anad Ahmad Dhuha Sabah Nadir \\ College of Education of pure science/ University of Diy ala

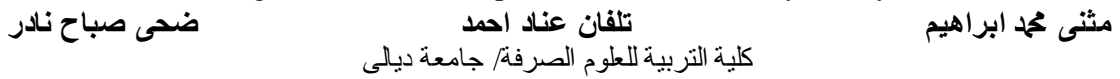

E-mail:sadeh1970@gmail.com

\begin{abstract}
The study was successful in establishing cell suspensions cultures derived from the hypocotyl callus of the plant Physalis angulata L. induced in the solid MS medium supplemented with the concentration of $3.0 \mathrm{mg}$. $\mathrm{L}^{-1}$ 2,4-Dichlorophenoxy acetic acid (2,4-D) plus $0.5 \mathrm{mg}$. $\mathrm{L}^{-1}$ Kinetin(Kin). The culture of the suspensions by different densities $(12.36,13.70,14.75,15.98) \times 10^{5} \mathrm{cell}^{3} \mathrm{~cm}^{3}$ using the plating and embedding methods by agar layer in the solid Murashige and Skoog medium (MS) enriched with the same callus induction concentrations, showed that the plating method exceed the embedding method in the number of cellular colonies which reached the average of 79.4 and 15.0 colony.dish ${ }^{-1}$ at the culturing density of $15.98 \times 10^{5} \mathrm{cell}^{-\mathrm{cm}^{3}}$, these values were declined with the primary density to reach the average of 14.0 and 11.4 colony.dish $^{-1}$ by both the plating and the embedding methods respectively, the high density significantly exceed all the rest densities and gave rate of callus primordia of 56.6 primordia.dish $^{-1}$ after 28 days from the day of culturing the suspended cells by plating method, and reached 9.8 primordia.dish $^{-1}$ after 33 days from the day of culturing of the suspended cells by using the embedding method, the transfer of the callus primordia to the MS medium supplemented with $3.0 \mathrm{mg}$. $\mathrm{L}^{-1} 2,4-\mathrm{D}$ plus $0.5 \mathrm{mg}$. $\mathrm{L}^{-1} \mathrm{Kin}$, led to the growth of callus segments and their differentiation to the somatic embryos and their development through all their stages until reaching the shoot formation.
\end{abstract}

Key words: Physalis angulata, cell suspension, callus.

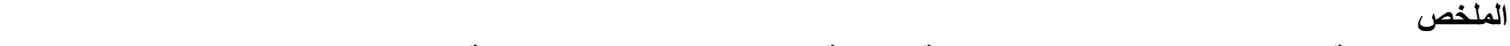

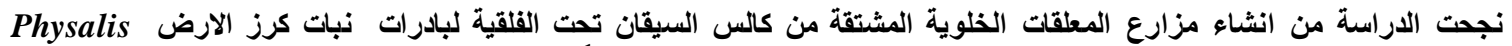
angulata L.

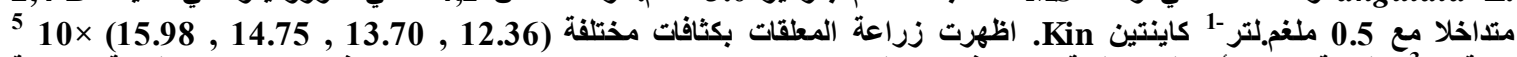

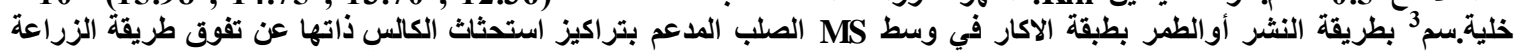

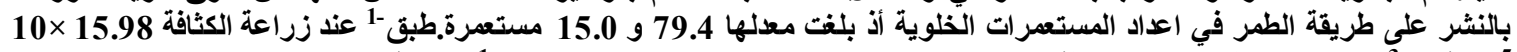

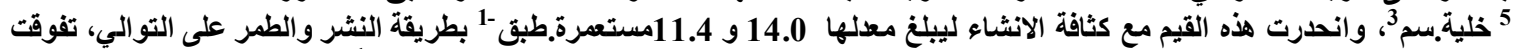

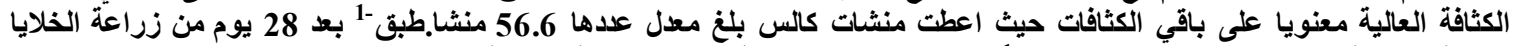

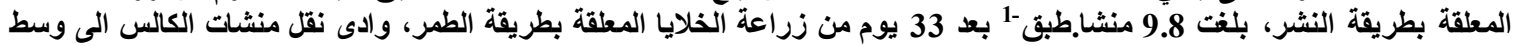

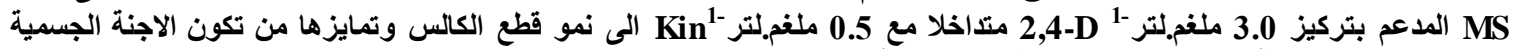
وتطور ها بمراحلها كافة وصولا الى ملى تكون الافرع الخضرية.

الكلمات المفتاحية: Physalis angulata، نبات كرز الارض، المعلق الخلوي، الكالس

Introduction

The genus Physalis belongs to the family Solanaceae and the species Physalis alkekengi is the most important species which is distributed in certain Iraqi territories [1], the species Physalis angulata, the studied species, was recorded in the first time among the Iraqi plant encyclopedia by [2]. This plant has medical importance because it was used for the treatment of hepatitis, asthma, urinary tract problems, rheumatis $m$ and cramps in addition to its pharmaceutical importance because it contains many secondary metabolites such as, alkaloids, phenols, tanins and steroids, it also has a nutritional importance due to the fact that it ripes fruits are edible as they contain carbohydrates, lipids minerals and vitamins $[3,4]$. 
The cell suspensions cultures are considered one of the important technologies in the field of plant tissue culture due to its vital application of which is the following:

- Good systemfor studying cells and their specialization.

- One of the suitable biological systems to obtain differentiated plants especially those having difficulty in their callus differentiation.

- Typical systems for studying the different metabolic pathways, enzyme induction and gene expression $[5,6]$.

- Cells and plant tissue culture became the fast typical source for the in vitro production of pharmaceutical compounds [7].

The present study aims to establish suspension cultures derived from callus of hypocotyl explant and to study the effect of cell densities when cultured by using both plating and embedding methods for callus formation.

Materials and Methods

- Induction of the hypocotyl explants to obtain callus

The seeds of Physalis angulata plant were surface sterilized by submersion in sodium hypochlorite solution $\mathrm{NaOCl}$ as described by [8]. The sterilized seeds were germinated on the surface of $20 \mathrm{ml}$ MS Solid medium [9], which were hormone free medium flasks $250 \mathrm{ml}$ at average of 5 seeds/ flask. The sterilized hypocotyl explants separated at the age of three weeks at length of $1.0 \mathrm{~cm} / \mathrm{segment}$ were used as explants to induce callus from them. They were transferred to glass flasks of $250 \mathrm{ml}$ each contained $50 \mathrm{ml}$ from the induction MS medium supplemented with $3.0 \mathrm{mg}$. $\mathrm{L}^{-1}$ 2,4-D plus $0.5 \mathrm{mg}$. $\mathrm{L}^{-1} \mathrm{Kin}$ [7].

\section{Establishment of cell suspensions derived from the hypocotyl explants}

A quantity 5 grams of friable callus induced on MS medium enriched with $3.0 \mathrm{mg}$. $\mathrm{L}^{-1}$ 2,4-D plus $0.5 \mathrm{mg}$. $\mathrm{L}^{-1}$ Kin. The callus was suspended in $50 \mathrm{ml}$ of liquid MS medium supplemented with the concentration on which each type of the used callus was induced in flasks of $250 \mathrm{ml}$ as shown by [10].

\section{Estimation of the density of cell suspension culture}

The total number of cells in the culture was estimated for each age group after 24, 48, 72 hours after titration in addition to the primary density (the zero group after the titration) by using the hemocytometer slide (Lab. W. Germany).

\section{- Cellular suspensions culture}

Two methods of cultures were used which are:

\section{- Plating method}

The plating method described by [11] was used with some modifications on the plastic Petri dishes of $9 \mathrm{~cm}$ diameter which contained thin layer of solid MS medium enriched with the same concentrations of plant growth regulators used in the established cellular suspension cultures. The growing cells of the suspension which grown were cultured on liquid a medium supplemented with $3.0 \mathrm{mg}$. L $\mathrm{L}^{-1}$ 2,4-D+ $0.5 \mathrm{mg}$. $\mathrm{L}^{-1} \mathrm{Kin}$ using the following densities 12.36, 13.70, 14.75, 15.98× $10^{5}$ cell. $\mathrm{cm}^{3}$ drawn from the suspension by using sterilized $1 \mathrm{ml}$ pipette and grown by plating method on the medium. Petri dishes were kept in the growth room at $25 \pm 2^{\circ} \mathrm{C}$ and covered by $\mathrm{A} 4$ white papers to avoid direct light and at consecutive light period of 16 hour light / 8 hours dark.

\section{- Embedding method:}

The embedding method described by[10] was used, $10 \mathrm{ml}$ from the cellular suspension of hypocotyl explants were used at the densities $(12.36,13.70,14.75,15.98) \times 10^{5} \mathrm{cell}^{\mathrm{c}} \mathrm{cm}^{3}$ grown in MS medium enriched with $3.0 \mathrm{mg}$. L $\mathrm{L}^{-1} 2,4-\mathrm{D}+0.5 \mathrm{mg}$. $\mathrm{L}^{-1} \mathrm{Kin}$ as described by [11].

The experiment of suspension culture was applied by using the complete Randomized Design (CRD) as a simple experiment at different densities, each density was repeated 10 times, to compare the different densities depending on Duncan test at probability level of 0.05 was used [13].

\section{- Regular test of cells and the follow-up of cellular colonies}


The cells of the cellular suspensions grown in the Petri dishes by both the plating and embedding methods were examined after 24 hours from culture then follow- up their division until the formation of colonies which gave callus primordial. The whole required data were collected for the numbers of cellular colonies, the number of the callus primordial were developed to small aggregates.

\section{Transfer of callus primordial and their maintenance}

The formed callus from the cellular suspensions culture of both the plating and embedding methods were transferred when they reached certain size to the surface of $20 \mathrm{ml}$ of MS medium supplemented with the same concentrations into $100 \mathrm{ml}$ glass flasks for their growth and reproduction. The percentage of growth regulators the developed calli, fresh weight, the color and texture were recorded after one month from culture. Then all the growing callus aggregates were transferred to a solid MS medium. The stages of the somatic-embryos were followed-up until the shoots appearance.

\section{Results and Discussion}

\section{- Typical cell suspensions induced from the callus of the hypocotyl explant}

The results confirmed that the induction medium of the liquid $\mathrm{MS}+3.0 \mathrm{mg}$. $\mathrm{L}^{-1} 2,4-\mathrm{D}+0.5 \mathrm{mg}$. $\mathrm{L}^{-1} \mathrm{Kin}$ showed its suitability for the primordia of cellular suspensions cultures from the friable callus of hypocotyl explant with very little increase in the cells number at the fourth day of the primordia on MS medium fortified with 2,4-D interacted with Kin. The cultures of the cellular suspensions contained numbers of single cells, the cellular masses were absent and this medium encouraged the cells growth and their first division after 24 hour from their suspension in reference with the increase in the density of suspended cultures relative to their primary density which was $12.36 \times 10^{5}$ cell. $\mathrm{cm}^{3}$, to continue their division showing Linear growth the density reached $15.98 \times 10^{5}$ cell. $\mathrm{cm}^{3}$ in the fourth day of their establishing Figure (1).

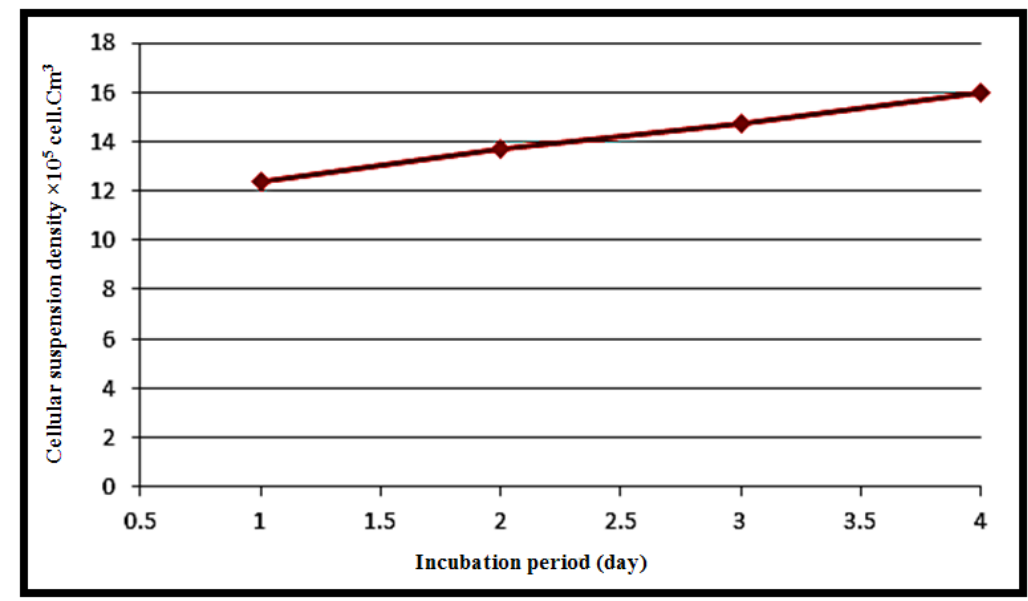

Fig. (1): Curves for the growth of cells suspensions derived from the friable callus of hypocotyl explant in the MS medium supplemented with of $3.0 \mathrm{mg}$. $\mathrm{L}^{-1}$ 2,4-D + 0.5 mg. $\mathrm{L}^{-1} \mathrm{Kin}$.

- Behaviors of the cellular suspensions derived from the callus of the hypocotyl explants induced on the MS medium enriched with 2,4-D and Kin and their products when cultured by plating method

The results of culturing variable densities of the cellular suspensions derived from the callus of hypocotyl by using plating method on the MS medium enriched with $3.0 \mathrm{mg}$. $\mathrm{L}^{-1}$ 2,4-D+ $0.5 \mathrm{mg}$. $\mathrm{L}^{-1} \mathrm{Kin}$, showed variation in the numbers of the formed cellular colonies and their products from the callus primordia Table (1).

Table (1): Effect of culturing variable densities from the cellular suspensions derived from the callus of hypocotyl explants segments of Physalis angulata in the solid MS medium supplemented with3.0 mg. $\mathrm{L}^{-1}$ 2,4-D+ $0.5 \mathrm{mg}$. $\mathrm{L}^{-1}$ Kin by both plating and embedding methods. 


\begin{tabular}{|c|c|c|c|c|}
\hline \multirow[b]{2}{*}{$\begin{array}{c}\text { Culturing density }\left(\times 10^{5}\right. \\
\left.\text { cell. } \mathrm{cm}^{3}\right)\end{array}$} & \multicolumn{2}{|c|}{ Plating method } & \multicolumn{2}{|c|}{ Embding method } \\
\hline & $\begin{array}{l}\text { The average } \\
\text { number of the } \\
\text { cellular } \\
\text { colonies.dish } \\
\text {-1 }\end{array}$ & $\begin{array}{l}\text { The average number of } \\
\text { the callus primordia } \\
\text { primordia.dish }\end{array}$ & $\begin{array}{l}\text { The average } \\
\text { number of the } \\
\text { cellular } \\
\text { colonies.dish }\end{array}$ & $\begin{array}{l}\text { The average number of the } \\
\text { callus primordia } \\
\text { primordia.dish }\end{array}$ \\
\hline $\begin{array}{l}\text { 12.36 (establishing } \\
\text { density) }\end{array}$ & 14.0 B & $8.0 \mathrm{~B}$ & $11.4 \mathrm{~A}$ & $2.8 \mathrm{~B}$ \\
\hline 13.70 & $20.0 \mathrm{~B}$ & $10.6 \mathrm{~B}$ & $12.6 \mathrm{~B}$ & $4.6 \mathrm{AB}$ \\
\hline
\end{tabular}

No. of replicates $=10$

The culturing density of $15.98 \times 10^{5}$ cell. $\mathrm{cm}^{3}$ recorded the highest value in the numbers of colonies which was 79.4 colony.dish ${ }^{-1}$ compared with their numbers obtained from culturing of primary density which reached 14.0 colony.dish ${ }^{-1}$. The results indicated that the development of cellular colonies to callus primordia increased directly with increment of the culturing density, which recorded the highest value of the number of the formed primordia which were 56.6 primordia.dish ${ }^{-1}$ using culturing density of $15.98 \times 10^{5}$

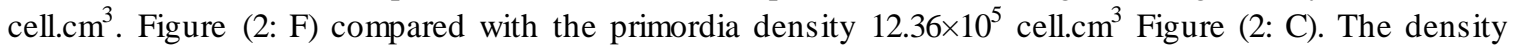
$13.70 \times 10^{5}$ cell.cm $\mathrm{cm}^{3}$ Figure (2: D) and the density $14.75 \times 10^{5}$ cell.cm ${ }^{3}$ Figure (2: E) recorded values of 8.0 , 10.6, 18.0 primordia.dish ${ }^{-1}$ respectively. Examinations by using the light microscope indicated that the cells of cultured suspensions started their first division after 24 hours forming colonies Figure (2: A) and continued their consecutive (sequential) divisions producing the cellular colonies which were formed from large numbers of cells Figure (2: B) after 15 days and they developed later to the callus primordia which appeared as white or pale green minute tis sue segments which can be seen by the naked eye on the surface of the medium after time period of 28 days depending on the culturing density.

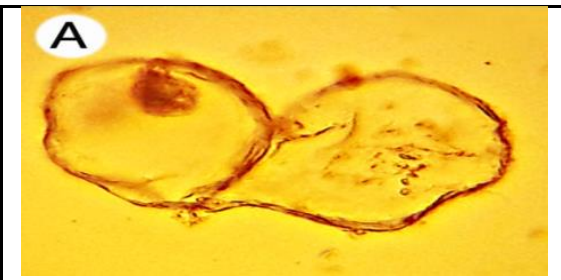

The first division of the cells of cellular suspension distributed on the solid medium after $72 \mathrm{~h}$ from the culturing

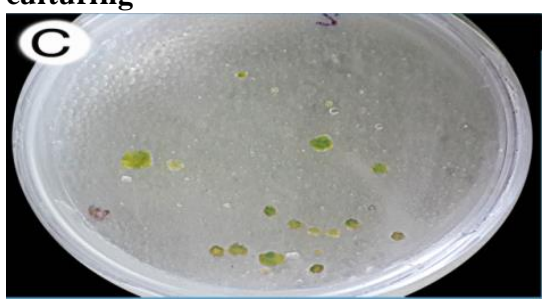

The callus primordia formed by the culturing the primordia density of $12.36 \times 10^{5}$ cell. $\mathrm{Cm}^{3}$ of the cellular suspensions after 28 days from the culturing

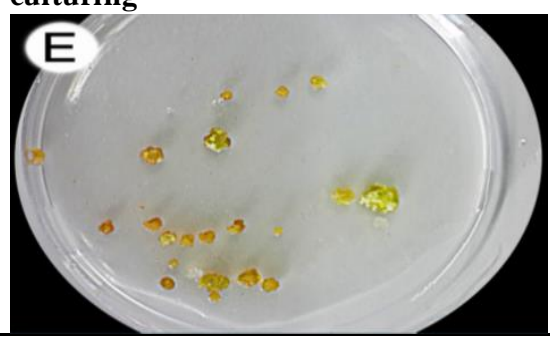

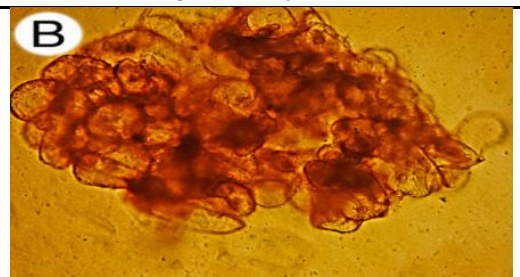

Cellular colony produced from (A) by the continuous division during $\mathbf{1 5}$ days from the culturing

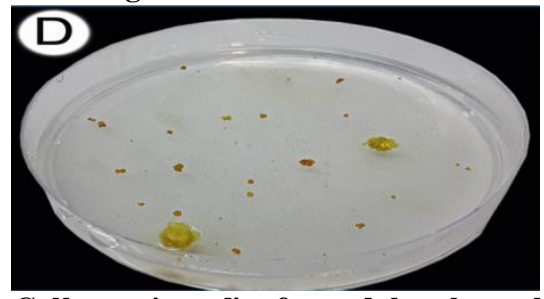

Callus primordia formed by the culturing density of $13.70 \times 10^{5}$ cell. $\mathrm{Cm}^{3}$ of the cellular suspensions after 28 days from culturing

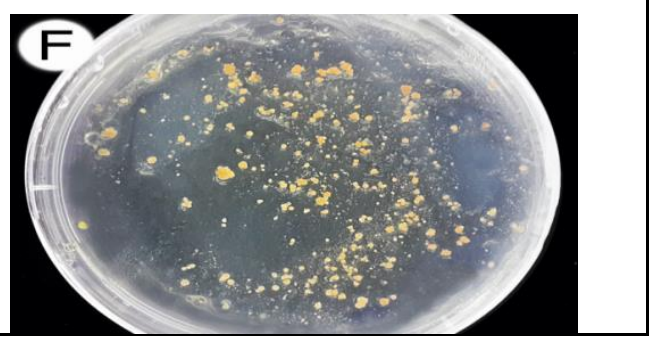




\begin{tabular}{|ll|}
\hline $\begin{array}{l}\text { Callus primordia formed by the culturing density } \\
\text { of } 14.75 \times 10^{5} \text { cell. } \mathrm{Cm}^{3} \text { of the cellular suspensions }\end{array}$ & $\begin{array}{l}\text { Callus primordia formed by the culturing } \\
\text { density of } 15.98 \times 10^{5} \text { cell. } \mathrm{Cm}^{3} \text { of the cellular } \\
\text { after } 28 \text { days from culturing }\end{array}$ \\
suspensions after 28 days from culturing
\end{tabular}

Fig. (2): The stages of the formation of the callus primordia by culturing the cellular suspension derived from the hypocotyl explants of Physalis angulata in the solid MS medium enriched with $3.0 \mathrm{mg} . \mathrm{L}^{-1} 2,4-\mathrm{D}+0.5 \mathrm{mg}^{-L^{-1}}$ Kin using the plating method.

- Behaviors of the cellular suspensions derived from the callus of the hypocotyl explants induced on the MS medium enriched with 2,4-D and Kin and their products when cultured by embedding method The results of culturing variable densities from the cellular suspensions derived from the callus of the hypocotyl explants by using the embedding method in the MS medium supplemented with $3.0 \mathrm{mg}$. $\mathrm{L}^{-1} 2,4-$ D+ $0.5 \mathrm{mg} . \mathrm{L}^{-1} \mathrm{Kin}$, showed variations in the numbers of the formed cellular colonies and their products from the callus primordial Table (1) despite of the absence of the significant variations between the culturing densities, the densities of $15.98,14.75 \times 10^{5}$ cell. $\mathrm{cm}^{3}$ significantly exceeded the treatment of the primordia density in the numbers of callus primordia, their numbers reached 9.8,8.8 primordia.dish $^{-1}$ respectively after 35 days from the culturing of the suspended cells Figure (3: C, D). Whilst the average number of callus primordial was 4.6 primordia.dish ${ }^{-1}$ for the $13.70 \times 10^{5} \mathrm{cell}^{\mathrm{cm}} \mathrm{cm}^{3}$ Figure (3: B) which does

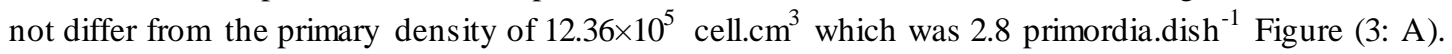

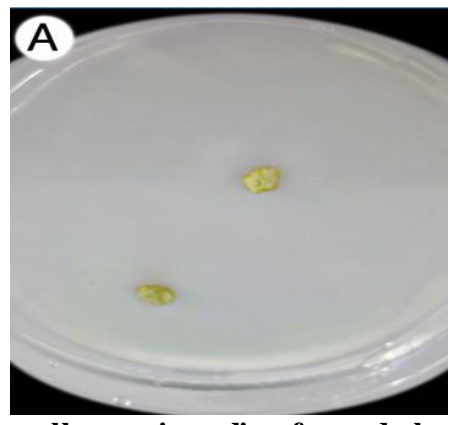

The callus primordia formed by the culturing of the primordia density of $\mathbf{1 2 . 3 6}$ $\times 10^{5}$ cell. $\mathrm{Cm}^{3}$ of the cellular suspensions after 35 day from the culturing.

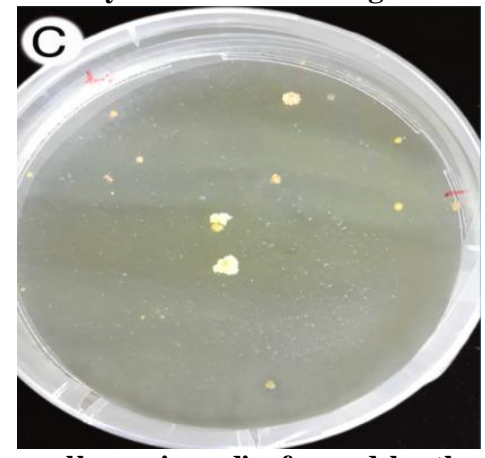

The callus primordia formed by the culturing density of $14.75 \times 10^{5}$ cell. $\mathrm{Cm}^{3}$ of the cellular suspensions after 35 day from the culturing.

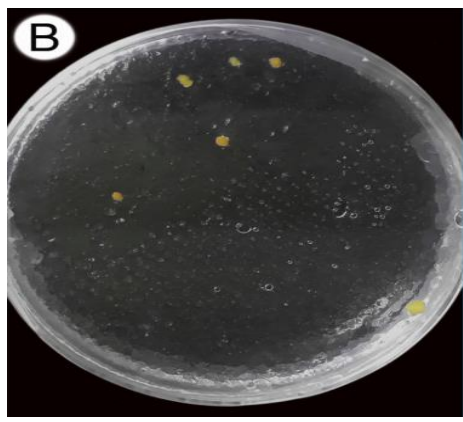

The callus primordia formed by the culturing density of $13.70 \times 10^{5}$ cell. $\mathrm{Cm}^{3}$ of the cellular suspensions after 35 day from the culturing.

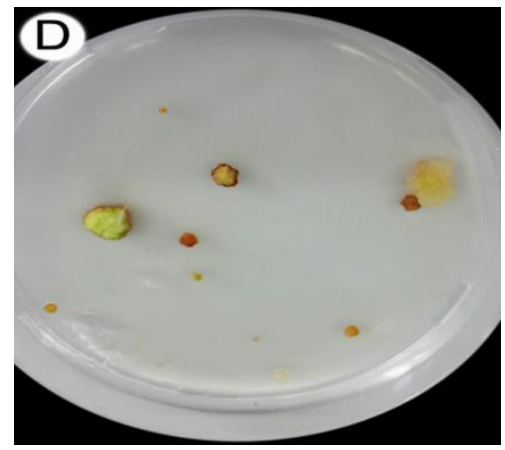

Callus primordia formed from the culturing density of $15.98 \times 10^{5}$ cell. $\mathrm{Cm}^{3}$ of the cellular suspensions after 35 day from the culturing.

Fig. (3): The stages of the formation of the callus primordia by culturing the cellular suspension derived from the hypocotyl explants of Physalis angulata in the solid MS medium enriched with $3.0 \mathrm{mg}^{-1}$ 2,4-D + $0.5 \mathrm{mg}$. $\mathrm{L}^{-1}$ Kin using the embedding method.

- The regular maintenance of the callus primordia 
The results of transferring the callus segments formed by culturing the cellular suspensions of the hypocotyl explants by using both the plating method and embedding method to fresh media indicated their growth, the percentage of the transferred segment response reached $90 \%$ and the average fresh weight of the callus primordia was $0.591 \mathrm{~g}$ in the MS medium supplied with $3.0 \mathrm{mg} . \mathrm{L}^{-1} 2,4-\mathrm{D}+0.5 \mathrm{mg}$. $\mathrm{L}^{-1} \mathrm{Kin}$, the derived callus from culturing the formed callus primordia was characterized by the variation of its color from solid dark green, pale globular green, yellow friable callus and solid white globular.

One of the important results of this study is the retransfer of the callus segments to the MS medium supplemented with $3.0 \mathrm{mg} . \mathrm{L}^{-1} 2,4-\mathrm{D}+0.5 \mathrm{mg}$. $\mathrm{L}^{-1}$ Kin led to the differentiation of these aggregates to branches through the formation of the somatic embryos the appearance of its stages, which are the globular, heart and torpedo stage were observed then the cotyledonary which were cap by the shoot appearance Figure (4: A, B, C).

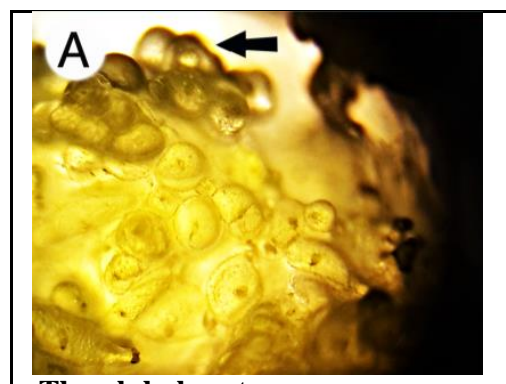

The globular stage.

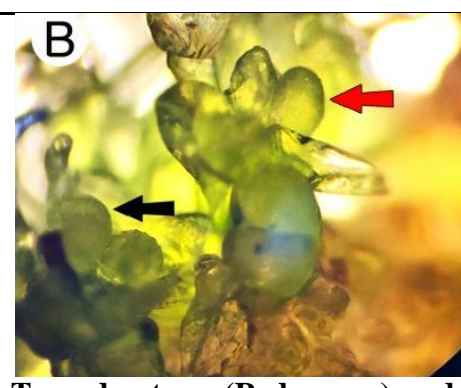

Torpedo stage (Red arrow) and the heart stage (Black arrow).

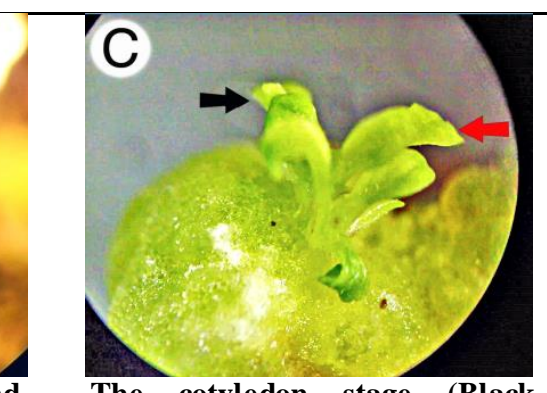

The cotyledon stage (Black arrow) and the stage of the real leaves (Red arrow).

Fig (4): The stages of the development of different somatic embryos from cellular suspensions on MS medium supplemented with $3.0 \mathrm{mg}$. $\mathrm{L}^{-1} 2,4-\mathrm{D}+0.5 \mathrm{mg}$. $\mathrm{L}^{-1} \mathrm{Kin}$ by using the plating method for Physalis angulata.

Cellular suspensions represent a new direction in the field of biotechnology for the plants through their use as typical systems, not for the purpose of callus obtaining, but by its supplying of a large field for the follow-up of single cells division, growth and differentiation [14]. The importance of present study lies in using the technology of establishing the cellular suspensions derived from the callus, to determine the necessary critical density for cells division and growth, then follow-up the cells division behavior and overcome the difficulty of callus differentiation. The results of this study showed the success of using the liquid MS medium enriched with $3.0 \mathrm{mg}$. $\mathrm{L}^{-1}$ 2,4-D+ $0.5 \mathrm{mg}^{-\mathrm{L}^{-1}} \mathrm{Kin}$ in establishing cellular suspensions which conserve its biomass, the success of these suspensions is due to the friable callus texture and the used quantity which was one of the reasons of success in establishing these cultures. It also depends on the medium constituents in addition to the continuous movement to ensure equal distribution of cells in the culture medium; the cells of transferred callus are dissociated from each other by the continuous movement to form cellular suspension that contains large numbers of single cells [15].

In this study we obtained callus primordia by culturing the cellular suspensions using both plating method and embedding methods $[11,10]$ in MS medium fortified with $3.0 \mathrm{mg}$. $\mathrm{L}^{-1}$ 2,4-D+ $0.5 \mathrm{mg}$. $\mathrm{L}^{-1} \mathrm{Kin}$, which can be explained to the fact that this plays active role in stimulating the division of unspecialized cells and also increases the stimulation rate and callus tissue growth, the activity of auxin concealed in the cellular wall, plasma membrane and the nucleic acids [16]. In addition to the cell division activity of cells and its continuation until the formation of small clumps of callus this can be attributed to the energetic activity between the large groups of single cells [17].

The results clearly showed that the resulting increase in the formation of primordia of callus derived from the cells of the cellular suspensions derived from hypocotyl explants using the plating method compared with the embedding method, which can be due to the cells immersion inside the medium that leads to make the anaerobic surrounding environment which caused death of the cells [16]. These results are in agreement 
with those obtained by [12], for the superiority of the plating method of cellular suspensions of the plant Withania somnifera in the MS medium supplemented with the concentration of $3.0 \mathrm{mg}$. $\mathrm{L}^{-1}$ 2,4-D+ $0.5 \mathrm{mg}$. $\mathrm{L}^{-1} \mathrm{Kin}$, on the embedding method in the numbers of the formed cellular colonies and the developed callus primordia, the results also indicated that the rate of development of callus resulted from culturing of the cellular suspension was higher compared with the induced callus from hypocotyl stems segments, this may be attributed that not all cells are in mutual contact with the medium in the callus tissues cultures [15], in addition to the difference between the behavior of the callus derived from the cellular suspensions and the behavior of the callus that derived from the explants due to its expected biogenesis from the single cells or from a mass of undifferentiated cells which may be differed from the differentiated cells that are found in the explants used for the callus induction, this explains the potentiality of overcoming the difficulties that associate with callus [18]. The appearance of the somatic embryos stages is due to the factors that determine their formation linked to genetic structure, tissue type, its evolutionism stage, growth regulators and its added concentration to the medium. 2,4-D is considered the most common auxin that stimulates somatic embryos biogenic in addition to the role of the used Kinetin that stimulated the formation of the embryos. The callus from which it was originated was a genetic type that is called pro-embryonic masses [19], which have the ability of cell division as a response, to the influential organic compounds such as the ratio of auxin to the cytokines [20].

\section{References}

1. Al-Samarai, K. W. A. (1983). Distribution of alkaloids in some wild species from the Solanaceae family in Iraq. M.Sc. Dissertation College of Science, University of Baghdad.

2. Al-Alaq, S. A. G. (2006). Morphological and Anatomical for selective wild species from the family Solanaceae in Iraq M. SC Dissertation, Women College of Science, University of Baghdad.

3. Silva, M.T., Simas, S.M., Batista, T.G., Cardarelli, P. and Tomassini, T.C. (2005). Studies on antimicrobial activity, in vitro, of Physalis angulata L. (Solanaceae) fraction and physalin B bringing out the importance of assay determination. Memordum Institute Oswaldo Cruz, Rio de Janeiro, 100(7): 779-782.

4. Elisalva, G., Milena, L., Luana, S., Ivon, R., Therezinha, C., Ricardo, S., Washington, S. and Milena, S. (2009). Activity of physalin purified from Physalis angulata in in vitro and in vivo models of cutaneous leishmaniasis. J. of Antimicrobial Chemotherapy, 64:84-87.

5. Fowke, L. C. and Wang, H. (1992). Protoplast as tools in cell biology. Physiology Plant, 85:391-395.

6. Lendevai, A., Nikovics, K., Bako, L., Dutits, D. and Gyorgey, J., (2002). Synochronization of Oryza sativa L. C.V. Taipei-309 Cell Suspension Culture. Acta Biology, 46 (3-4): 39-41.

7. Karuppusamy, S. (2009). A review on trends in production of secondary metabolites from higher plants by in vitro tissue, organ and cell cultures. J. Medical plant Research, 3: 1222-1239.

8. Hatam, S. M. (2016). Callus induction and the medical plant formation of Physalis angulata L. and the detection of Physalin in the callus and its differentiated plants. M. Sc. Dissertation, College of Education for pure Sciences, University of Diyala.

9. Murashige, T. and Skoog, F. (1962). A revised medium for rapid growth and bioassays with tobacco cultures. Physiology Plant, 15: 473-497.

10. Dixon, R.A. (1985). Plant cell cultures. A Practical Approach. IRL Press, Oxford, UK.

Morris, P., Webb, K. J., Robbins, M. P. and Jorgenesen, B. (1999). Application of Biotechnology to Lotus breeding. News Letter Science and Technology, 28:199-228.

11. Bedrgman, L. (1960). Growth and division of single cells of higher plants in vitro. J.General Physiology, 43:841-851.

12. Alwan, B. M. (2016). Cooperation between the planting and the array in the Steroid Withanaloid production in the cellular suspensions for the plant Withania simnofera. M. Sc. Dissertation, College of Education for pure Sciences, University of Diyala.

13. Victor, M.L. and Felipe, V. (2006). Plant Cell Culture Protocols. $2^{\mathrm{Ed}}$. Humana Press International, Totowa, N.J.

14. Rashid, G. H. and Qasim, S. W. (2006). The role of thermal treatment in the preparation of the cellular division and callus formation from the cellular suspensions for the sun flower Helianthus annus in the multiple Agar drops. J. of Al-Rafidin Agriculture, 24 (2).

15. Ramawat, K. G. (2008). Plant Biotechnology. S. Chand and Company Ltd. third edition, New Delhi, India. 
16. Devlin, R. M. and Witham, F. H. (1983). Plant Physiology. $4^{\mathrm{Ed}}$. Wadsworth Publishing Company, Belmont California, U. S. A.

17. Cuddihy, A. E. and Bottino, P. J. (1982). Winged-bean Protoplast: Isolation and culture to callus. Plant cell tissue and Organ Culture, 1:201-209.

18. Morris, P., Webb, K. J., Robbins, M. P. and Jorgensen, B. (1999). Application of Biotecnology to Lotus breeding. News Letter Science and Technology, 28:199-228.

19. Al-Sumaidai, K. M. I. (2017). Plant technological application, Vol. 1, Ministry of Higher Education and Scientific Research.

20. Salman, M. A. (1988). Principles of plant cells and tissues culture. Dar Al-Kutub for publishing and distribution, University of Mousl. 